IJMS 18 (1), 173-196 (2011)

\title{
KEMISKINAN DAN AGIHAN PENDAPATAN DI NEGERI PERAK
}

\author{
ZAKARIAH ABDUL RASHID \\ NOORAINI KAMARUL BAHRAIN \\ Fakulti Ekonomi \& Pengurusan \\ Universiti Putra Malaysia
}

\begin{abstract}
Abstrak
Dengan menggunakan data HIS2000 dan pengiraan beberapa indeks kemiskinan dan agihan pendapatan (positif dan normatif), kertas kajian ini menganalisis isu kemiskinan dan jurang pendapatan mengikut kaum dan wilayah dalam negeri Perak. Kajian ini mendapati kemiskinan di negeri ini berdimensikan kaum dan wilayah apabila isi rumah Melayu adalah yang paling ramai miskin dengan jurang pendapatan di antara kaum ini dengan kaum-kaum lain jelas ketara. Selain itu, kemiskinan negeri ini juga bercirikan luar bandar dengan jurang pendapatan antara bandar dengan luar-bandar juga jelas ketara. Bagi memperbaiki ketidakseimbangan ini, kertas ini mencadangkan agar kaum yang terkebelakang ekonominya diberikan peluang yang lebih baik bergiat dalam sektor pembuatan dan perkhidmatan dan begitu juga, kawasan luar bandar perlu ditingkatkan prasarana ekonominya. Kedua-dua cadangan ini boleh diselaraskan dalam satu strategi pembangunan yang sedia ada dalam peringkat negeri dan persekutuan (NCER).
\end{abstract}

Kata kunci: Ukuran kemiskinan positif dan normatif, pencerakinan agihan pendapatan, nisbah jurang pendapatan dan ukuran kebajikan.

\begin{abstract}
By using HIS2000 data set and deriving a few indices of poverty and income distribution (positive and normative), the present paper analyses poverty and income gap issues by ethnic and regional differences in Perak. The paper found that poverty in the state has ethnic and regional dimensions as Malay households dominate the poverty scene and inter-ethnic income gap is considerable. Similarly, poverty in the state is characterized by the rural area as the regional income gap is prominent. To overcome the state of disequilibrium, the paper suggests that economically-backward ethnic
\end{abstract}


groups be given more opportunity to participate in the manufacturing and service activities, and similarly rural economic infrastructure be uplifted. Both these recommendations can be integrated into the existing development strategy at the state and the federal (NCER) levels.

Keyword: Positif and normative measurement of poverty, de compotion of income distribution, income gap ratio and welfare measure.

\section{Pengenalan}

Walaupun prestasi ekonomi makro sesebuah negara adalah baik namun apabila rakyat masih resah dengan kehidupan harian yang menghimpit ekonomi mereka, itu adalah petanda bahawa ekonomi negara tersebut sedang menghadapi masalah pengagihan kekayaan negara dan kemiskinan. Pandangan yang lain berpendapat bahawa apalah gunanya kekayaan negara yang tinggi jika tidak diagihkan secara adil. Walaupun pendapatan bukanlah pengukur mutlak kebahagiaan, namun ia perkara pokok dalam pertumbuhan ekonomi sesebuah negara. Ketidakseimbangan agihan pendapatan boleh menimbulkan masalah-masalah ketidakstabilan ekonomi ${ }^{1}$.

Walaupun pendapat yang berpengaruh mengatakan bahawa menggunakan data pendapatan bukan merupakan cara yang sempurna untuk mengukur kemiskinan lantas (Sen, 1987;1999) mencadangkan tumpuan harus diberikan kepada keupayaan asas seseorang individu, konsep yang penting ini sukar untuk digunakan dalam kerja-kerja praktik (Brandolini, 2001). Sibley (2007) mengulangi pendapat Sen dengan mengatakan kemiskinan tidak hanya dikaitkan dengan kekurangan wang. Haveman dan Bershadker (2001) mengemukakan penyelesaian dengan satu kaedah yang dapat mengukur prestasi ekonomi yang boleh mencegah kemiskinan melalui keupayaan kendiri.

Dengan konsep kemiskinan yang pelbagai dimensi, Wade (2001); Li dan Schwaub (2004) mengaitkan kemiskinan dengan ketidakseimbangan pendapatan, ketidakselamatan yang meningkat serta kekejaman global. Manakala, Abbott dan Pollard (2004) mendefinisikan kemiskinan sebagai ketidakcukupan untuk mengekalkan pembangunan manusia yang disebabkan oleh kesukaran mendapatkan perkhidmatan asas seperti pendidikan dan kesihatan, mengambil peluang sosioekonomi dalam masyarakat serta mendapatkan sumber yang cukup untuk memenuhi keperluan asas isi rumah. 
Adams Jr dan Page (2003) mencadangkan agar migrasi dan peluang pekerjaan sektor awam sebagai satu daripada langkah-langkah yang boleh digunakan untuk mengurangkan masalah kemiskinan. Pendapat yang sangat berpengaruh ialah pertumbuhan ekonomi yang pantas boleh mengurangkan kemiskinan (Jackson, 1984; Simons, 1996), tetapi belum tentu untuk mengurang jurang agihan pendapatan kerana Papanek dan Kyn (1985) mendapati bahawa tiada hubungan yang sistematik di antara agihan pendapatan dan kadar pertumbuhan ekonomi negara. Ravallion (1997), Alesina dan Rodrik (1994) dan Persson dan Tabellini (1994) pula mempunyai pandangan yang bertentangan, yakni ketidakseimbangan pendapatan akan berkurang apabila kemiskinan dapat dikurangkan dalam tempoh pertumbuhan ekonomi yang pesat.

Pengangguran boleh berlaku dalam suasana ketidakseimbangan agihan pendapatan. Pengangguran dalam kalangan graduan institut pengajian tinggi di Malaysia (Lucas \& Verry, 1996) amat ketara ketika negara tersebut menikmati pertumbuhan ekonomi yang mapan tetapi ketidaksetaraan agihan yang tinggi. Begitu juga, ketidaktentuan harga komoditi pertanian pula adalah penyebab kemiskinan di luar bandar. Hal ini bermakna pembangunan luar bandar boleh membantu mengurangkan masalah kemiskinan (Mahadevan, 2006); Fang, Zhang \& Fan, 2002).

Kaum peribumi Melayu merupakan kaum yang paling ramai miskin yang kebanyakan mereka bekerja sebagai petani dan buruh ladang dan mendiami kawasan luar bandar. Ramai pengkaji mendapati bahawa pelaburan dalam infrastruktur di kawasan tersebut boleh memberi kesan yang positif dan maksima ke atas penduduk luar bandar lantas mengurangkan penghijrahan ke bandar serta mengurangkan kemiskinan ${ }^{2}$.

\section{Kemiskinan dan Agihan Pendapatan di Malaysia}

Rancangan Malaysia ke-9 (RMK9), 2006-2010 yang merangka Misi Nasional dijangka dapat mengembangkan ekonomi pada kadar 6 peratus. Seperti dalam rancangan-rancangan pembangunan jangka panjang yang lalu, RMK9 juga menitikberatkan isu kemiskinan dan agihan pendapatan. Banyak projek dan program telah dirancang untuk mengurangkan kemiskinan dan ketidakseimbangan agihan pendapatan ini, misalnya program khas untuk meningkatkan pembangunan sosioekonomi penduduk luar bandar agar dapat mengurangkan jurang pembangunan di antara bandar dan luar bandar. 
Setelah menyedari bahawa jurang pendapatan antara bandar dan luar bandar semakin melebar, daripada 1:1.81 pada tahun 1999 kepada 1:2.11 pada tahun 2004 dan kadar kemiskinan yang semakin tinggi terutama di negeri yang kurang membangun', RMK9 mengatur strategi bagi merapatkan jurang tersebut dengan membangunkan kawasan luar bandar. Antara strategi yang dirancang ialah mempergiatkan pembangunan pusat pertumbuhan luar bandar, meningkatkan aktiviti ekonomi, menyediakan kemudahan sosial dan menggalakkan pembangunan modal insan. Selain itu, program latihan kemahiran bagi golongan belia di luar bandar juga akan disediakan untuk meningkatkan keupayaan mereka mendapatkan pekerjaan. Tambahan pula, peratusan penduduk di bandar dijangka meningkat kepada 63.8 peratus pada tahun 2010 hasil daripada penghijrahan golongan belia dari luar bandar, perluasan kawasan bandar dan peningkatan peluang pekerjaan di bandar. Perkara ini semua memberikan cabaran baharu dalam menangani masalah jurang pendapatan ini.

Berdasarkan Pendapatan Garis Kemiskinan (PGK) ${ }^{4}$, pada tahun 2004 kaum Bumiputera adalah golongan teramai yang miskin tegar, 1.9 peratus berbanding dengan kaum Cina, 0.1 peratus, dan India, 0.3 peratus. Kemiskinan di kawasan luarbandar walaupun berkurangan kepada 11.9 peratus pada tahun 2004 dari 14.8 peratus pada tahun 1999, namun sebilangan besar rakyat miskin 70.6 peratus daripada jumlah isi rumah masih menetap di kawasan luar bandar.

Pembentukan Wilayah Ekonomi Koridor Utara (NCER) yang merangkumi negeri Perlis, Kedah, Pulau Pinang dan Perak Utara, di samping menjadi strategi kerajaan untuk mempercepatkan pembangunan ekonomi dan meninggikan tahap pendapatan penduduk di wilayah utara Semenanjung Malaysia, juga bermatlamat untuk mengurangkan kemiskinan dan ketidakseimbangan pendapatan $^{5}$.

Kertas kajian ini diatur sedemikian: Bahagian II menghuraikan latar belakang sosioekonomi negeri Perak dengan diikuti oleh Bahagian III yang menghuraikan rangka kerja teoritikal dan data kajian. Bahagian IV pula membincangkan dapatan kajian disusuli dengan Bahagian $\mathrm{V}$ menyimpulkan perbincangan kertas kajian ini.

\section{Latar Belakang Sosioekonomi Negeri Perak}

Negeri Perak Darul Ridzuan yang meliputi kawasan seluas 21,005 km persegi iaitu 6.4 peratus daripada jumlah keluasan Malaysia adalah 
negeri yang kedua terbesar di Semenanjung Malaysia. Mengikut bancian tahun 2000, unjuran tahun 2004, bilangan penduduk negeri Perak ialah 2.2 juta orang yang terdiri daripada 57 peratus kaum Melayu, 25 peratus kaum Cina dan 18 peratus kaum India. Secara purata negeri Perak mencatatkan jumlah kadar kenaikan jumlah penduduk sebanyak 1.4 peratus setahun 6 . 60 peratus dari penduduk Perak adalah di kawasan bandar manakala selebihnya 40 peratus adalah di kawasan luar bandar. Jadual 1 menunjukkan pecahan penduduk mengikut daerah dan keluasannya.

Jadual 1

Keluasan ( $\mathrm{km}^{2}$ ) dan Jumlah Penduduk Mengikut Daerah, 2004

\begin{tabular}{lcc}
\hline Daerah & Keluasan & Jumlah Penduduk \\
\hline Batang Padang & 2,712 & 159,083 \\
Hilir Perak & 1,728 & 198,743 \\
Hulu Perak & 6,563 & 86,462 \\
Kerian & 958 & 159,430 \\
Kinta & 1,958 & 735,030 \\
Kuala Kangsar & 2,541 & 150,244 \\
Larut, Matang \& Selama: & 2,095 & 249,455 \\
Manjung & 1,171 & 199,809 \\
Perak Tengah & 1,279 & 85,532 \\
\hline
\end{tabular}

Sumber: Jabatan Ukur dan Pemetaan Negeri Perak

Negeri Perak menduduki tempat ketujuh jika diukur dari segi pembangunan negeri-negeri di Malaysia menggunakan Indeks Komposit Pembangunan dengan nilai indeks 100.4 pada tahun 2005. Perak dianggar dapat meningkatkan kadar pertumbuhan tahunan purata Keluaran Dalam Negeri Kasar kepada 5.7 peratus di dalam RMK9 berbanding 4.1 peratus dalam rancangan sebelumnya. Kadar yang sentiasa meningkat ini didorong oleh sektor pertanian, pembuatan dan perkhidmatan. Sektor perkhidmatan merupakan sektor yang paling tinggi menyumbang kepada pendapatan negeri Perak. Pendapatan isi rumah bulanan purata di negeri Perak juga menunjukkan peningkatan iaitu RM1,743 pada tahun 1999 kepada RM2,207 pada tahun 2004. Unjuran jumlah penduduk di Perak pada tahun 2010 ialah seramai 2.44 juta orang. Negeri Perak dijangka menghadapi kadar pertumbuhan perbandaran kepada 59.3 peratus pada tahun 2010. Manakala kadar pertumbuhan tahunan purata bagi penduduk bandar pula adalah 1.6 peratus. 
Kerajaan negeri Perak mempunyai rancangan pembangunannya tersendiri yang dilaksanakan melalui pecahan empat koridor.

(i) Koridor Utara, yang terdiri daripada Daerah Kerian, Larut Matang dan Selama, serta Kuala Kangsar menumpu kepada perindustrian, perumahan dan pelancongan. Antara produk yang dihasilkan dalam koridor ini ialah pembangunan tasik Bukit Merah, pembangunan bercampur Lembah Beriah, pembangunan pelancongan yang berkonsepkan ekopelancongan (hutan paya laut Kuala Sepetang dan pemeliharaan burung Kuala Gula), warisan sejarah dan komersial (taman tema, zoo) dan kawasan peranginan tanah tinggi, Bandar Diraja (institusi dan sejarah) dan industri kecil dan sederhana.

(ii) Koridor Tengah merupakan wilayah koridor yang paling luas meliputi Daerah Kinta, Perak Tengah dan Manjung. Wilayah ini memfokuskan ke arah industri komersial, perindustrian, pelancongan, institusi awam dan swasta serta industri maritim. Produk yang dihasilkan ialah pusat pentadbiran negeri, pusat kecemerlangan pendidikan, pusat pelancongan antarabangsa, Gugusan Pulau Sembilan sebagai Taman Laut, pusat perindustrian dan menjadikan Lumut sebagai bandar pelabuhan.

(iii) Koridor Timur Laut, yang merangkumi Daerah Hulu Perak dan Selama, menumpu kepada pertanian, ekopelancongan dan penyelidikan. Pelbagai produk yang dihasilkan, antaranya penyelidikan pertanian, biotek, perhutanan, perkayuan dan pembangunan institusi pendidikan, Pulau Banding, Royal Belum, Kawasan Industri Bebas Cukai, Kawasan Perindustrian Northgate di Pengkalan Hulu dan Muzium Arkeologi Lenggong.

(iv) Koridor Selatan yang meliputi Daerah Batang Padang dan Hilir Perak. Fokus utama wilayah ini ialah pendidikan, pertanian, pelancongan dan industri automotif. Produk-produk yang dihasilkan ialah Bandar Proton, Universiti Pendidikan Sultan Idris, Institut Ukur dan Tanah Negara di Behrang, Politeknik Sultan Azlan Shah di Tanjung Malim, papaya cluster, industri perkapalan kecil, jelapang padi, hasil perikanan dan pelancongan.

Di samping pembangunan yang dirancang oleh kerajaan negeri, wilayah Perak Utara juga termasuk dalam projek pembangunan 
terbaru kerajaan persekutuan, iaitu Wilayah Ekonomi Koridor Utara (NCER). Perak Utara yang meliputi empat daerah iaitu Hulu Perak, Kerian, Kuala Kangsar dan Larut Matang-Selama. Fokus utama rancangan ini di Perak Utara adalah untuk memodenkan pertanian terutama di daerah Kerian. Manakala industri pembuatan dan pelancongan akan difokuskan di daerah Taiping. Di daerah Selama pula akan dibangunkan sektor akuakultur di Kuala Sepetang. Sektor pelancongan akan lebih ditumpukan di Hulu Perak di mana terletaknya Hutan Belum, ia juga boleh menjadi pusat penyelidikan herba bioteknologi. Selain itu, Parit Buntar dan Taiping akan dipastikan menjadi tempat pelaburan industri elektrik dan elektronik $(\mathrm{E} \& \mathrm{E})^{7}$.

Kedudukan pembangunannya yang agak terkebelakang walaupun saiz geografi negeri Perak yang besar berbanding dengan negerinegeri lain mendesak negeri ini mempercepatkan pertumbuhan ekonominya. Walaupun demikian ia terpaksa berhadapan dengan isu pengagihan pendapatan yang tidak saksama dan kemiskinan akibat daripada kawasan luar-bandar dan bilangan kaum Melayu yang ramai miskin. Masalah ini tambah runcing kerana negeri ini masih bergantung kuat kepada kegiatan pertanian sebagai salah satu penyumbang pendapatan negeri. Oleh kerana produk pertanian mempunyai pasaran harga yang tidak menentu, ini telah menimbulkan masalah kepada petani-petani dan secara tidak langsung kepada pendapatan negeri. Akibatnya, petani tidak mempunyai pendapatan yang stabil dan menyebabkan berlakunya kemiskinan dalam kalangan mereka.

Ketidaksetaraan agihan pendapatan dalam negeri Perak mempunyai dimensi wilayah dan kaum. Perbezaan sosioekonomi antara kaum masih lagi wujud dan ia menjadi satu cabaran kepada kerajaan negeri untuk mengurangkan perbezaan tersebut bagi meningkatkan lagi pembangunan ekonomi negeri.

Perak merupakan sebuah negeri yang luas dan mempunyai geografi fizikal yang pelbagai yang boleh mewakili Semenanjung Malaysia secara keseluruhannya. Kertas kajian ini mengkaji kemiskinan dan agihan pendapatan dari segi kumpulan etnik dan wilayah bandar dan luar bandar di negeri Perak Darul Ridzuan. Walaupun pemilihan negeri ini dan tahun kajian boleh menjadi persoalan, kajian ini dilakukan berdasarkan kepada data yang ada. Walau bagaimanapun, kajian ini lebih merupakan kajian penerokaan kerana kajian kemisikinan dan agihan pendapatan isi rumah bagi sesebuah negeri dalam Malaysia, yang sedia termaklum oleh penulis, belum pernah dilakukan. 


\section{Metodologi}

Data pendapatan isi rumah dan ahli-ahlinya, merangkumi pendapatan yang diperoleh daripada gaji dan pendapatanpendapatan lain dari hasil pertanian yang diusahakan, dan daripada pendapatan hasil sewaan harta seperti tanah, rumah dan terimaan dalam bentuk bayaran pindahan seperti biasiswa, bantuan-bantuan lain ataupun pencen. Data pendapatan ini dikelaskan mengikut penerima-penerima pendapatan dan isi rumah. Sesebuah isi rumah, yang mempunyai pelbagai bilangan ahli, boleh mempunyai lebih dari seorang penerima pendapatan, dan pendapatan mereka dianalisis mengikut jumlah pendapatan isi rumah dan purata pendapatan ahli.

Kajian ini menggunakan sampel data Household Income Survey bagi tahun 2000 (HIS2000) yang dikutip oleh Jabatan Perangkaan Malaysia bagi negeri Perak dan meliputi semua daerah termasuk kawasan bandar dan luar bandar dan semua kaum. Walaupun data kajian ini agak lama, namun berdasarkan sumber data yang terhad dan dengan mengambil kira segala kelemahan persampelan data ini, kajian ini ingin menunjukkan bahawa kajian kemiskinan dan agihan pendapatan boleh dilakukan dengan menggunakan sumber data ini.

Bagi mengkaji agihan pendapatan, kajian ini mengira pekali Gini yang dicerakinkan mengikut sumber pendapatan yang pelbagai dan indeks Atkinson. Bagi mengkaji kemiskinan pula, kajian ini mengira kadar kemiskinan secara head-count, jurang kemiskinan dan indeks FGT. Kajian ini juga mengkaji agihan pendapatan dan kemiskinan mengikut pecahan kawasan (bandar dan luar bandar) dan mengikut kaum (Melayu, Cina, India dan kaum-kaum lain). Pendapatan isi rumah adalah jumlah pendapatan yang diperoleh oleh sesebuah isi rumah yang berlainan saiz dan boleh diperoleh daripada seorang atau lebih penerima pendapatan. Manakala pendapatan purata pula adalah pendapatan yang diperoleh oleh seorang penerima pendapatan, yang boleh diperoleh dari isi rumah yang sama.

Biasanya maklumat ketidaksetaraan keseluruhan bagi pendapatan tidak memadai untuk mensasar sesuatu dasar awam dengan tepat dan dasar sebenar boleh memberi kesan yang berbeza ke atas sesuatu jenis pendapatan (misalnya, gaji dan bukan gaji) justru adalah penting kita memisahkan indeks ketidaksetaraan di antara pelbagai punca pendapatan. Tambahan lagi, mencerakin indeks ketidaksetaraan melalui punca pendapatan samalah seperti kita menyiasat struktur ketidaksetaraan, yakni memisahkan ketidaksetaraan keseluruhan kepada faktor-faktor tertentu. Usaha sedemikian juga membantu 
kita menganalisis kesan sesuatu dasar pembangunan ke atas ketidaksetaraan dengan cara analisis agihan pendapatan. Cerakinan seperti ini juga menambah faham kita sama ada ketidaksetaraan keseluruhan tertumpu kepada sesuatu butiran pendapatan atau sebaliknya. Pertanyaan biasa yang diajukan ialah berapa besarkah ketidaksetaraan keseluruhan diterangkan oleh ketidaksetaraan dalam gaji, misalnya berapa besar ketidaksetaraan telah diterangkan oleh pendapatan pertanian? Pencerakinan pekali Gini kepada puncapunca pendapatan telah dicadangkan oleh Lerman dan Yitzhaki (1985) dan dikira dengan menggunakan persamaan (1),

$$
G=2 / \bar{y} \operatorname{Cov}[y, F(y)]=\underset{k=1}{m} 2 / \bar{y} \operatorname{Cov}[y k, F(y)]
$$

di mana $m$ ialah pelbagai sumber pendapatan dan $k$ ialah bilangan sumber pendapatan. Perhatikan, indeks Gini taburan pendapatan keseluruhan sama dengan jumlah (bagi semua $\mathrm{m}$ punca) pekali Gini yang dikira dengan menggunakan kovarian di antara punca pendapatan ke $k$ dan fungsi taburan kumulatif jumlah pendapatan. Persamaan pencerakinan tersebut menerangkan dari mana ketidaksetaraan pendapatan itu datang.

Kajian ini juga akan melukis keluk Lorenz ${ }^{8}$, yang dapat menggambarkan tahap ketidaksetaraan pendapatan dalam kalangan isi rumah di Perak dalam tahun 2000.

\section{Indeks Atkinson}

Dengan menggunakan konsep kebajikan sosial oleh Dalton, Atkinson memperkenalkan konsep paras pendapatan equally distributed equivalent $\left(\mathrm{Y}_{\mathrm{EDE} .}\right)$, yakni paras pendapatan per kapita yang sekiranya ia ditaburkan secara saksama akan memberikan paras kebajikan sosial yang sama dengan yang diperoleh oleh taburan pendapatan yang terdapat pada masa kini, yakni persamaan (2) menunjukkan,

$$
U\left(Y_{E D E}\right) \int_{0}^{y^{\prime}} f(y) d y=\int_{0}^{y^{\prime}} U(y) f(y) d y
$$

Pendapatan "equally distributed equivalent, $\left(Y_{E D E}\right)$ " diperoleh dengan membahagikan pendapatan purata golongan miskin, $m$ dengan $\left(1-G_{p}\right)$. Maka, $Y_{E D E}=\frac{m}{\left(1-G_{p}\right)}$, dimana $m$ ialah pendapatan 
purata golongan miskin, dan $G_{p}$ ialah pekali Gini golongan miskin. Indeks Atkinson ditakrifkan seperti yang ditunjukkan dalam persamaan (3) sebagai,

$$
I=1-\frac{Y_{E D E}}{\mu}
$$

Yakni 1 tolak nisbah paras pendapatan equally distributed equivalent kepada taburan sebenar purata. Jika $I$ jatuh, taburan kini menjadi lebih saksama. I berada di antara 0 (kesetaraan sempurna) dan 1 (ketidaksetaraan sempurna). Dalam taburan diskret, rumus di atas boleh ditunjukkan seperti dalam persamaan (4) dan menjadi;

$$
I=1-\left[\sum_{i}\left(\frac{y_{i}}{\mu}\right)^{1-\epsilon} f\left(y_{i}\right)\right]^{1 /(1-\epsilon)}
$$

Di mana $\in$, ialah ukuran degree of inequality aversion, atau sensitiviti relatif sesuatu pindahan pada sesuatu pindahan pada sesuatu paras pendapatan. Dengan $\in$ yang meningkat, lebih wajaran diberikan kepada pindahan pada hujung bawah taburan dan kurang wajaran kepada pindahan pada hujung atas.

Kajian ini juga akan menganggar pendapatan equally distributed equivalent, $\mathrm{Y}_{\text {ede }^{\prime}}$ yakni satu paras pendapatan yang dapat menghasilkan tahap kebajikan yang sama dengan tahap kebajikan yang diterima daripada jumlah pendapatan yang diperoleh dalam masa kini.

\section{Dapatan dan Perbincangan}

Dapatan kajian ini semata-mata berdasarkan kepada data sampel HIS2000 lantas segala kelemahan dalam sampel ini terpakai juga dalam dapatan ini. Kajian ini juga mengukur kadar kemiskinan berdasarkan pendapatan garis kemiskinan tahun 2000 yang ditetapkan pada paras RM510 sebulan dengan purata saiz isi rumah seramai 4.6 orang 9 .

Kajian ini meneliti data pendapatan isi rumah mengikut kaum (Melayu, Cina, India dan kaum lain) dan kawasan (bandar dan luar bandar). Sampel kami mendapati 7,683 orang penerima pendapatan, yang terdiri daripada 3,845 kaum Melayu, 2,518 kaum Cina, 1,112 
kaum India dan 208 penerima pendapatan dari kaum-kaum lain. Pecahan data ini mengikut kawasan pula mendapati terdapat 4,212 penerima pendapatan yang mendiami kawasan bandar manakala bakinya 3,472 penerima pendapatan menetap di luar bandar. (Rujuk Jadual 2)

Sampel kami juga mendapati 4,769 buah isi rumah, yang terdiri daripada 2,446 buah isi rumah Melayu, 1,603 buah isi rumah Cina, 583 buah isi rumah India, dan 137 buah isi rumah kaum-kaum lain. Pecahan data ini mengikut kawasan pula mendapati terdapat 2,521 buah isi rumah yang mendiami kawasan bandar manakala bakinya 2,251 buah isi rumah menetap di luar bandar. (Rujuk Jadual 2)

Jadual 2

Penerima Pendapatan (Bilangan Orang) dan Bilangan Isi Rumah di Negeri Perak Tahun 2000

\begin{tabular}{lcccccc}
\hline & \multicolumn{2}{c}{ Bandar } & \multicolumn{2}{c}{ Luar Bandar } & \multicolumn{2}{c}{ Jumlah } \\
\hline & $\begin{array}{c}\text { Penerima } \\
\text { Pendapatan }\end{array}$ & $\begin{array}{c}\text { Bilangan } \\
\text { Isi Rumah }\end{array}$ & $\begin{array}{c}\text { Penerima } \\
\text { Pendapatan }\end{array}$ & $\begin{array}{c}\text { Bilangan } \\
\text { Isi Rumah }\end{array}$ & $\begin{array}{c}\text { Penerima } \\
\text { Iendapatan }\end{array}$ & $\begin{array}{c}\text { Bilangan Isi } \\
\text { Rumah }\end{array}$ \\
\hline Melayu & 1,645 & 978 & 2,201 & 1,468 & 3,845 & 2,446 \\
Cina & 1,838 & 114 & 680 & 462 & 2,518 & 1,604 \\
India & 666 & 355 & 446 & 228 & 1,112 & 584 \\
Kaum lain & 63 & 45 & 145 & 92 & 208 & 137 \\
Jumlah & 4,212 & 2,521 & 3,472 & 2,251 & 7,863 & 4,769 \\
\hline
\end{tabular}

Selain itu, sampel kami mendapati orang Melayu merupakan kaum yang paling ramai menetap di kawasan luar bandar (2,201 buah isi rumah) berbanding kawasan bandar (1,645 buah isi rumah). Ini berlawanan dengan kaum Cina yang lebih ramai menetap di kawasan bandar (1,838 buah isi rumah) berbanding dengan kawasan luar bandar (680 buah isi rumah). Manakala, bagi kaum India 446 buah isi rumah menetap di luar bandar manakala 666 buah isi rumah menetap di kawasan bandar. (Rujuk Jadual 3)

Sampel kajian kami mendapati purata pendapatan tahunan bagi sebuah isi rumah di negeri Perak ialah RM20,890.24 (Rujuk Jadual 3). Isi rumah yang menerima pendapatan di antara RM10,000 hingga RM20,000 adalah golongan yang paling ramai (1,896 buah isi rumah). Sampel ini juga mendapati hanya 39 buah isi rumah memperoleh pendapatan tertinggi di antara RM100,000 dan ke atas). (Rujuk Jadual 4) 
Jadual 3

Purata Pendapatan Tahunan Isi Rumah (RM) di Perak Tahun 2000

\begin{tabular}{lccc}
\hline & Bandar & Luar Bandar & Jumlah \\
\hline Melayu & $23,990.24$ & $14,849.14$ & $18,502.59$ \\
Cina & $27,436.71$ & $19,871.38$ & $25,257.67$ \\
India & $22,720.31$ & $17,672.77$ & $20,749.69$ \\
Kaum-kaum lain & $19,167.44$ & $9,304.92$ & $12,544.44$ \\
Jumlah & $25,286.05$ & $15,939.32$ & $20,890.24$ \\
\hline
\end{tabular}

Jadual 4

Bilangan Isi Rumah mengikut Selang Pendapatan di Perak pada Tahun 2000

\begin{tabular}{rrrrrr}
\hline & Cina & India & Melayu & Kaum Lain & Jumlah \\
\hline $0-10 \mathrm{k}$ & 264 & 107 & 695 & 73 & 1,139 \\
$10 \mathrm{k}+$ & 602 & 271 & 971 & 52 & 1,896 \\
$20 \mathrm{k}+$ & 285 & 104 & 424 & 4 & 817 \\
$30 \mathrm{k}+$ & 198 & 51 & 166 & 5 & 420 \\
$40 \mathrm{k}+$ & 114 & 23 & 95 & 1 & 233 \\
$50 \mathrm{k}+$ & 60 & 21 & 41 & 0 & 122 \\
$60 \mathrm{k}+$ & 22 & 3 & 20 & 0 & 45 \\
$70 \mathrm{k}+$ & 20 & 2 & 5 & 1 & 28 \\
$80 \mathrm{k}+$ & 5 & 0 & 9 & 0 & 14 \\
$90 \mathrm{k}+$ & 10 & 0 & 6 & 0 & 16 \\
$100 \mathrm{k}++$ & 23 & 1 & 14 & 1 & 39 \\
Jumlah & 1,603 & 583 & 2,446 & 137 & 4,769 \\
\hline
\end{tabular}

\section{Kemiskinan}

Berdasarkan sampel isi rumah, dengan menggunakan head count kajian ini mendapati Perak mempunyai kadar kemiskinan sebanyak 9.6 peratus dalam tahun 2000. Menyedari kelemahan kaedah ini, kajian ini mengira jurang kemiskinan yang mengukur jumlah pendapatan untuk membebaskan setiap orang miskin daripada belenggu kemiskinan dengan menambahkan pendapatan mereka ke paras PGK. Secara purata golongan miskin menerima pendapatan bulanan sebanyak RM363.4910. Negeri ini memerlukan setiap isi

184 IJMS 18 (1), 173-196 (2011) 
rumah miskin (sampel kami berjumah 459 isi rumah) diberi purata tambahan pendapatan sebanyak RM146.51 sebulan jika kita ingin melepaskan diri mereka daripada belenggu kemiskinan, yakni purata jurang kemiskinan sebesar 28.7 peratus. Kita juga telah mengira indeks ${ }^{11} \mathrm{FGT}_{2}$ yang lumrah digunakan dalam kajian antarabangsa dan indeks kita memberikan nilai 0.1147. Indeks ini mengatasi kaedah head count dengan memenuhi prinsip sensitiviti pengagihan (Rujuk Jadual 5 ).

Orang Melayu adalah kaum yang paling ramai miskin (316 buah isi rumah) berbanding dengan kaum-kaum lain (Cina 90 buah isi rumah, India 22 buah isi rumah, kaum-kaum lain 31 buah isi rumah) sama ada yang berada di kawasan bandar ataupun di kawasan luar bandar. Namun begitu, tidak seperti isi rumah Melayu yang bilangan mereka yang miskin lebih tinggi di kawasan luar bandar (275 buah isi rumah) berbanding bandar (41 buah isi rumah), bilangan isi rumah Cina yang miskin lebih ramai di kawasan bandar (56 buah isi rumah) berbanding kawasan luar bandar (34 buah isi rumah). Begitu juga dengan kaum India yang mempunyai bilangan isi rumah miskin sebanyak 12 buah isi rumah di kawasan bandar dan 10 buah isi rumah di luar bandar; manakala kaum-kaum lain pula tidak mempunyai golongan miskin di kawasan bandar tetapi hanya terdapat 31 buah isi rumah miskin di kawasan luar bandar. Secara keseluruhannya, isi rumah miskin di luar bandar (350 buah isi rumah) adalah lebih tinggi daripada yang di bandar (109 buah isi rumah) di Perak. Ringkasnya, isi rumah miskin di Perak bercirikan kaum Melayu (68.84 peratus) dan luar bandar (76.25 peratus). (Rujuk Jadual 6)

\section{Agihan Pendapatan Isi Rumah}

Dengan memperoleh pekali Gini bagi pendapatan isi rumah 0.3937 bagi negeri Perak dalam tahun 2000, ia menggambarkan ketidaksetaraan agihan pendapatan yang lebih baik dibandingkan dengan pekali Gini nasional. Sebahagian besar (71.1 peratus) daripada ketidaksetaraan tersebut adalah berpunca daripada pendapatan pekerjaan bergaji (0.28) sedangkan selebihnya dari sumbangan (28.8 peratus dengan nilai indeks 0.11) pendapatan-pendapatan lain ${ }^{12}$. Ini menunjukkan ketidaksetaraan pendapataan keseluruhan sebahagian besarnya disumbangkan dari ketidaksetaraan pendapatan bergaji, yakni jurang pendapatan bergaji adalah lebar. Implikasi daripada dapatan ini ialah jika matlamat memperbaiki ketidaksetaraan pendapatan keseluruhan ingin dicapai, jika usaha merapatkan jurang pendapatan bergaji berjaya dilakukan ia akan membantu secara yang amat berkesan dalam merapatkan jurang pendapatan keseluruhan. 


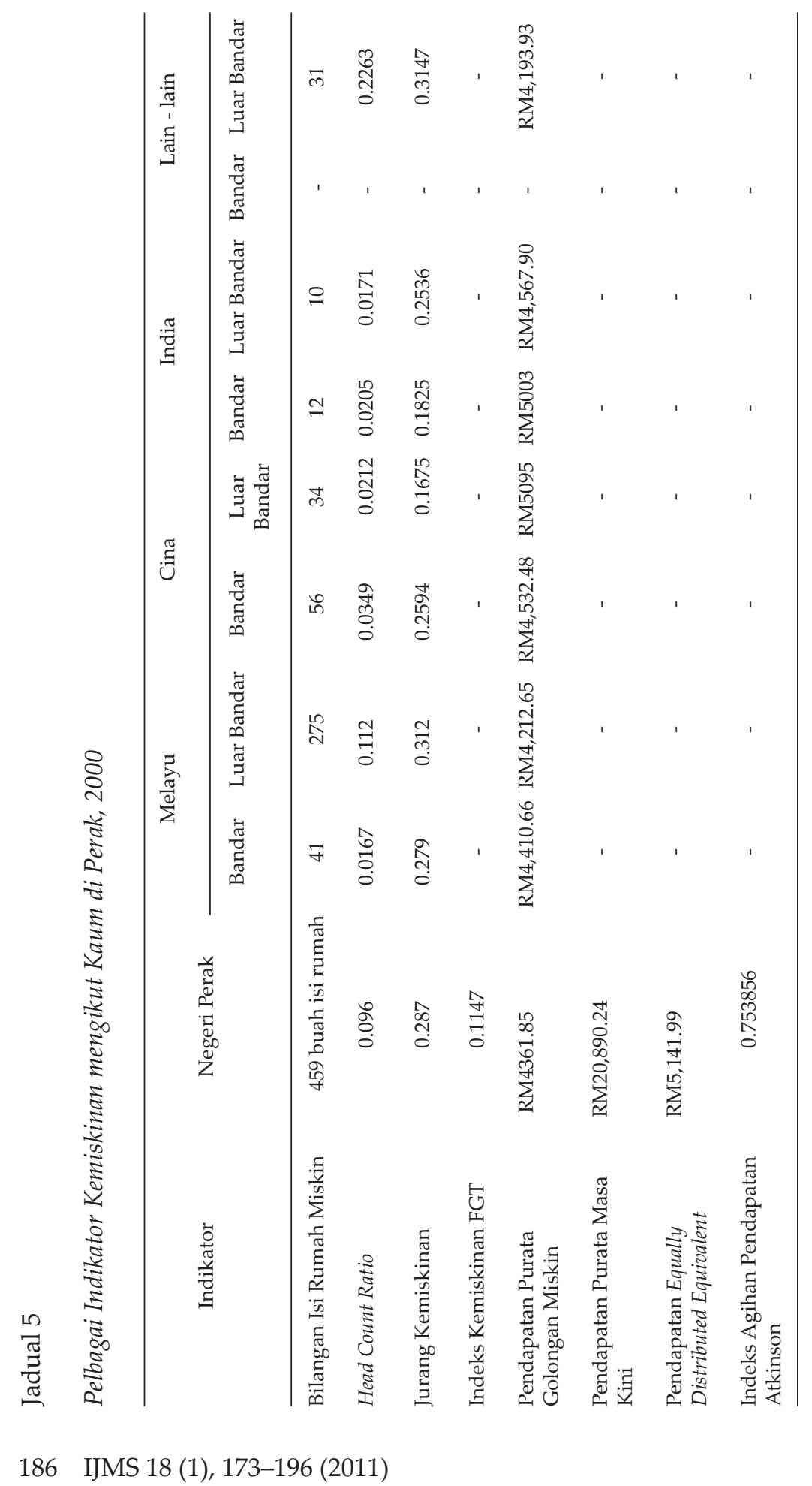




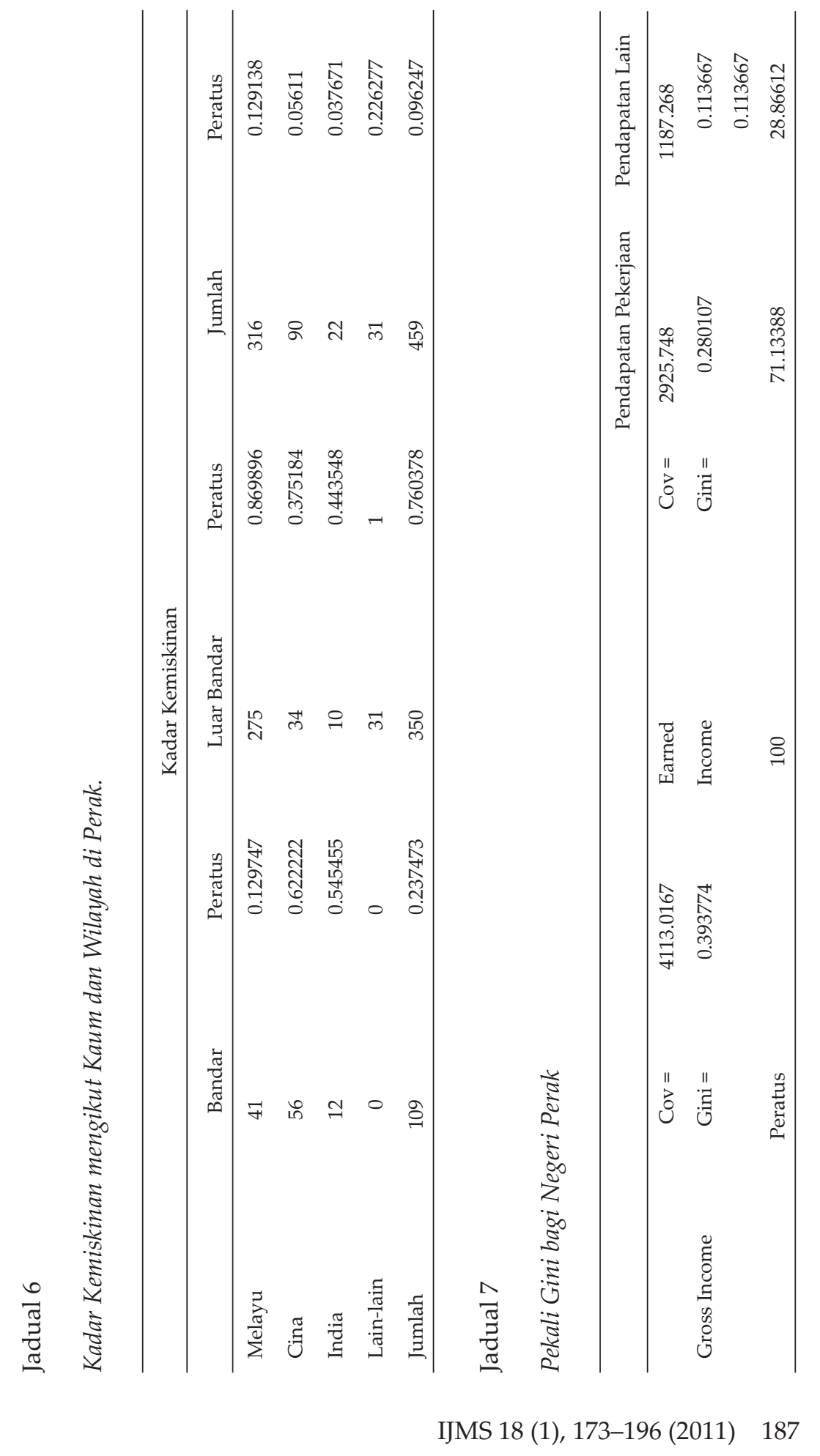


Dengan pendapatan (tahunan) purata golongan miskin sebanyak RM4,361.85, kita peroleh pendapatan equally distributed equivalent sebanyak RM5,141.99, menunjukkan bahawa seseorang individu di negeri Perak hanya memerlukan jumlah pendapatan yang sebanyak itu untuk mendapatkan tahap kebajikan yang sama dengan yang mereka peroleh dengan pendapatan (tahunan) purata masa kini (RM20,890.24). Ini menggambarkan pendapatan purata yang tinggi dan ketidaksetaraan pendapatan yang berlaku masa kini telah menjejaskan tahap kebajikan rakyat Perak.

Oleh itu Indeks Atkinson 0.753856 menunjukkan bahawa tahap dan agihan pendapatan masa kini dalam negeri Perak telah menjejaskan kebajikan penduduk sebanyak 25 peratus. Atau dengan kata lain, pendapatan boleh dikurangkan sebanyak 25 peratus daripada yang diperoleh pada masa kini dan pada masa yang sama tahap kebajikan masih boleh dikekalkan dengan agihan pendapatan yang saksama (lihat jadual 5). Ini bermakna negeri Perak berdepan dengan isu yang bertentangan antara pertumbuhan ekonomi yang pantas dengan tahap kebajikan rakyatnya.

Keluk Lorenz mendapati bahawa 80 peratus penerima pendapatan terkecil hanya menerima 54.10 peratus sahaja daripada jumlah keseluruhan pendapatan yang diagihkan. Jika dibandingkan dengan 20 peratus penerima pendapatan tertinggi memperoleh hampir 50 peratus pendapatan secara keseluruhan. (Rujuk Rajah 1)

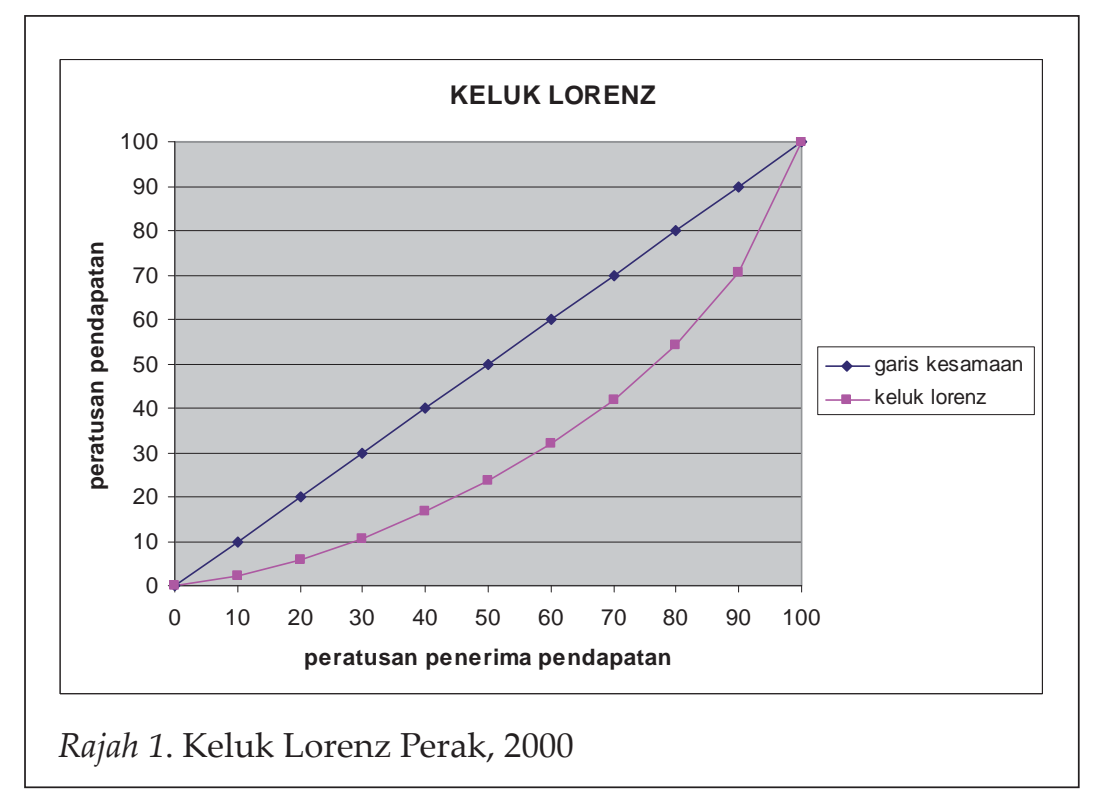




\section{Jurang Pendapatan}

Secara keseluruhannya, pendapatan di kawasan bandar adalah lebih tinggi daripada yang di luar bandar bagi setiap kaum. Purata pendapatan perseorangan bagi kaum Cina adalah yang tertinggi iaitu sebanyak RM16,072.78 dan sebaliknya kaum-kaum lain mencatatkan purata pendapatan perseorangan terendah iaitu sebanyak RM7,554.07. Nisbah jurang pendapatan bandar dan luar bandar menunjukkan jurang yang amat luas dalam kalangan kaum Melayu dan yang kecil dalam kalangan kaum India. Nisbah jurang pendapatan antara kaum pula menerangkan jurang pendapatan antara kaum. Kaum Cina memperoleh pendapatan 40 peratus lebih tinggi sedangkan kaum India lebih rendah 6 peratus daripada kaum Melayu (Rujuk Jadual 8).

Jika dilihat dari segi purata pendapatan tahunan isi rumah di negeri ini didapati kaum Cina mempunyai jumlah purata pendapatan yang lebih tinggi berbanding kaum-kaum lain (RM25,257.67). Sama seperti purata pendapatan perseorangan, purata pendapatan isi rumah juga adalah lebih besar di kawasan bandar (RM25,286.05) berbanding luar bandar (RM15,939.32). Nisbah jurang purata pendapatan antara kaum pula menunjukkan kaum Cina memperoleh lebih 37 peratus pendapatan berbanding kaum Melayu. Manakala, nisbah jurang pendapatan antara kawasan pula menunjukkan kawasan bandar memperoleh jumlah pendapatan 59 peratus lebih daripada kawasan luar bandar. Dapat dilihat juga terdapat jurang yang besar di antara lain-lain kaum di bandar dan luar bandar (106 peratus) (Rujuk Jadual 9).

\section{Rumusan dan Cadangan Dasar}

Malaysia telah menyaksikan peningkatan dalam pendapatan purata isi rumah tetapi kadar bagi antara kaum kelihatan tidak banyak berubah sedangkan bagi di antara bandar dan luar bandar menjadi semakin melebar, yang menyaksikan kadar bagi bandar semakin besar berbanding dengan bagi luar bandar. Justeru, jurang pendapatan antara kaum tidak ketara mengecil seperti yang diharapkan sedangkan bagi di antara bandar dan luar bandar semakin meluas. Jika trend sedemikian berterusan, matlamat untuk mendapatkan pendapatan yang sama rata di antara kaum dan antara bandar-luar bandar mustahil dapat dicapai dalam masa yang singkat, lantas ia menjadi cabaran yang getir kepada setiap Rancangan Malaysia yang akan datang. 


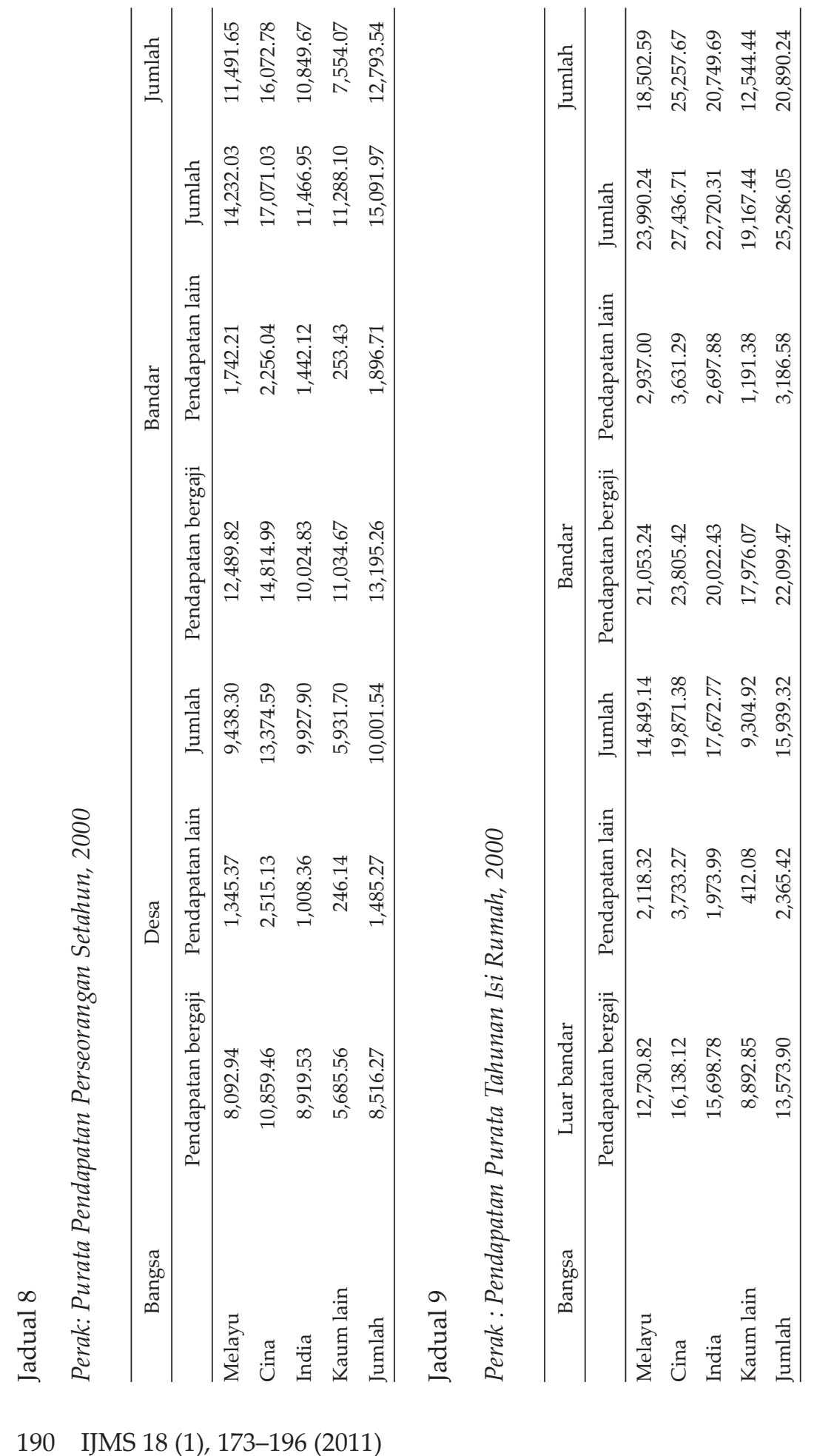


Dasar rancangan jangka panjang ekonomi Malaysia mengarah kepada pertumbuhan yang mapan dan pengagihan kekayaan negara yang sama rata di antara kaum dan bandar dan luar bandar (kedua-dua pencapaian matlamat ini biasanya saling menolak). Membandingkan pertumbuhan dan pengagihan dalam tempoh DEB dan tempoh selepasnya, tempuh yang disebut kemudian itu menyaksikan pertumbuhan yang lebih pantas tetapi pengagihan yang lebih perlahan. Ini mencerminkan objektif tempuh pertama itu lebih menumpukan kepada pengagihan sedangkan objektif tempoh kedua pula telah mengkesampingkan pengagihan bagi memberi ruang kepada pertumbuhan.

Sebagai negeri yang luas secara gerografinya, negeri Perak masih lagi wujud pengenalan kaum mengikut sektor ekonomi lantas masalah pengagihan seperti yang dijelaskan oleh DEB masih relevan. Walaupun kertas kajian ini tidak mengaitkan dengan data pekerjaan mengikut kaum, namun sorotan kajian dalam bidang ini menunjukkan bahawa kaum Cina mempunyai pendapatan yang lebih tinggi kerana kebanyakan mereka selain menduduki kawasan bandar juga menceburi bidang perniagaan. Dapatan kajian daripada kertas kajian ini juga menunjukkan terdapat jurang pendapatan antara etnik yang sangat nyata. Ini sangat berbeza dengan kaum-kaum lain seperti Melayu yang banyak bergiat dalam bidang pertanian dan India di estet-estet getah dan kelapa sawit. Walaupun, kerajaan cuba menjadikan bidang pertanian sebagai satu perniagaan, namun keberkesanannya untuk meningkatkan pendapatan kaum Melayu dan India masih kurang jelas. Satu kajian yang dapat menunjukkan daya penjanaan pendapatan mengikut kaum dalam kegiatan pertanian amat diperlukan, yang mana hasilnya dapat menunjukkan potensi keberkesanan strategi tersebut.

Kemiskinan dan ketidaksetaraan agihan pendapatan dalam kalangan rakyat negeri Perak adalah isu yang nyata. Pada umumnya, isi rumah miskin di Perak bercirikan kaum Melayu (68.84 peratus) dan luar bandar (78.57 peratus) serta jurang pendapatan antara kaum dan kawasan juga sangat jelas. Walaupun ketidaksetaraan agihan pendapatan di Malaysia sebahagian besarnya disumbangkan oleh ketidaksetaraan "dalam kumpulan" dan "bukan antara kumpulan"13 jurang pendapatan antara etnik begitu nyata sekali seperti yang dilaporkan dalam Rancangan Malaysia Ke-9. Dan tentu sekali jika sesuatu dasar berjaya mengurangkan jurang pendapatan antara etnik, keseluruhan ketidaksetaraan pendapatan akan dapat dikurangkan. Walau bagaimanapun, yang mana satukah sama ada mengurangkan ketidaksetaraan "antara kumpulan" atau yang "dalam kumpulan"

IJMS 18 (1), 173-196 (2011) 191 
yang lebih berkesan, kertas kajian ini tidak dapat menentukan. Apa yang pasti mengurangkan ketidaksetaraan pendapatan "antara kumpulan" sememangnya akan mengurangkan keseluruhan ketidaksetaraan.

Kita masih memerlukan kajian yang dapat memberikan arah yang jelas bahawa adakah benar pelaburan secara besar-besaran dalam membangunkan sektor pertanian akan menyelesaikan masalah yang dibincangkan ini? Jika kita meningkatkan produktiviti sektor pertanian dan sektor luar bandar sehingga jurang pendapatan di antara bandar dan luar bandar dikurangkan, apakah implikasinya kepada jurang pendapatan antara kaum pula? Satu kajian yang dapat menunjukkan pengganda pendapatan isi rumah mengikut kaum bagi sektor pertanian akan dapat memastikan sejauh manakah pelaburan dalam sektor pertanian akan menjana pendapatan isi rumah mengikut kaum dan saiz relatif pengganda ini akan dapat menjawab persoalan ini.

Walaupun isi rumah rakyat negeri ini dapat mencapai paras pendapatan purata yang tinggi seperti yang dilaporkan oleh UPEN Perak tetapi ia telah mengakibatkan indeks ketidaksetaraan pendapataan mereka terjejas berpunca daripada agihan yang tidak setara. Satu strategi pemindahan kekayaan, selaras dengan falsafah pemindahan yang terdapat dalam DEB, perlu diwujudkan untuk mempercepatkan aliran pemindahan tersebut kerana terlalu bergantung kepada kuasa pasaran untuk memperbaiki ketidakseimbangan ini tidak akan menjayakan hasrat DEB. Justeru, kerajaan negeri perlu merumus satu perseimbangan di antara pertumbuhan ekonomi dan kebajikan rakyat negeri ini. Apa yang jelas, skop memperbaiki tahap kebajikann rakyat negeri ini masih ada tetapi pada kos melepaskan pertumbuhan ekonomi negeri. Kadar penggantian antara keduanya, tidak pula jelas dalam kajian ini kerana diluar skop kajian.

Memandangkan kajian ini mendapati pendapatan kaum Melayu dan India jauh terkebelakang berbanding dengan kaum Cina, usaha meningkatkan pendapatan relatif isi rumah kaum Melayu dan juga bagi kaum India memerlukan satu dasar yang jelas yang dapat memindahkan orang Melayu dan India kepada kegiatan ekonomi yang lebih produktif, khususnya menambahkan bilangan mereka dalam sektor-sektor pembuatan dan tertiari (bidang bukan pertanian). Begitu juga oleh kerana kajian ini mendapati kaum Melayu adalah penduduk dominan luar bandar, dan bergiat dalam sektor pertama (kegiatan pertanian, penternakan dan perikanan), merekalah juga yang didapati miskin dan berpendapatan paling 
rendah. Lanjutan daripada dasar ini, begitu juga, orang Melayu dan India perlu diberi peluang yang lebih baik untuk menjawat pekerjaan yang terdapat di kawasan bandar, terutama dalam sektor pembuatan dan perkhidmatan asalkan mereka layak. Adalah dijangkakan jika penglibatan mereka dalam kegiatan ekonomi yang lebih produktif dapat ditingkatkan, masalah kemiskinan dan ketidaksamarataan agihan pendapatan mengikut kaum dan kawasan dapat diatasi serentak dengan amat berkesan.

Bagi meningkatkan pendapatan penduduk luar bandar agar jurang pendapatan bandar dan luar bandar dapat dikurangkan, kerajaan perlu mewujudkan lebih banyak projek-projek pembangunan di kawasan luar bandar. Selain itu, kerajaan juga perlu mencipta lebih banyak peluang-peluang pekerjaan di luar bandar bagi memberikan masyarakat luarbandar satu pekerjaan yang stabil dan tidak terlalu bergantung pada bidang pertanian yang mempunyai pasaran dan harga yang tidak menentu. Secara tidak langsung, ia dapat mengurangkan bilangan masyarakat luar bandar terutama golongan belia daripada berhijrah ke bandar. Projek dan program yang telah dirancang dalam pelan pembangunan negeri Perak dan NCER bukan sahaja perlu diselaraskan tetapi dilihat kembali dengan dasar pemindahan yang dinyatakan di atas.

Kertas kajian ini merumuskan bahawa masalah kemiskinan dan agihan pendapatan melibatkan pelbagai dimensi. Kerajaan negeri Perak harus menjawab pelbagai persoalan yang saling bertentangan yang berpaksikan kepada pertumbuhan ekonomi yang mapan di satu pihak dan kebajikan rakyatnya di pihak yang satu lagi: pembangunan bandar dan luar bandar, jurang antara kaum, dan jurang produktiviti pertanian dan bukan pertanian. Kertas kajian ini hanya mengukur jurang pengagihan pendapatan dan kemiskinan antara kawasan dan kaum. Ia tidak mengambil kira secara langsung aspek-aspek pelbagai dimensi ini yang berkaitan dengan isu-isu seperti faktor-faktor yang mendorong kepada berlakunya masalah agihan pendapatan dan kemiskinan tersebut.

\section{Nota Akhir}

1. Seperti kadar kematian dan kelahiran yang tinggi, tahap kesihatan dan nutrisi yang rendah dan masalah sosial yang sentiasa meningkat.

2. Rujuk Fan dan Chan (2005); Jha (2006); Culloch dan Calandrino (2003); Mehta dan Shah (2003); Renwei dan Shi (1997); Topalova (2005); Uphoff (2003). 
3. http://www.pmo.gov.my

4. Tahap kemiskinan di Malaysia ditentukan dengan merujuk kepada Pendapatan Garis Kemiskinan. Pendapatan Garis Kemiskinan (PGK), yang boleh dibahagikan kepada dua: (i) PGK makanan yang mengambil kira pemakanan seimbang yang diperoleh oleh sesebuah isi rumah. PGK makanan bagi Malaysia ialah RM415 sebulan. (ii) PGK bukan makanan yang meliputi pakaian, perumahan, pengangkutan dan perbelanjaan-perbelanjaan lain yang digunakan oleh isi rumah. PGK bukan makanan bagi kawasan luar bandar ialah RM687 dan bagi kawasan bandar ialah RM698.

5. NCER dijangka dapat menjana aktiviti ekonomi yang boleh menseimbangkan pembangunan semua sektor ekonomi. Aktiviti pertanian, perindustrian dan perkhidmatan dalam koridor ini akan dapat meningkatkan modal insan melalui pelaburan sektor swasta.

6. http://www.perak.gov.my

7. http:// www.ncer.com.my

8. Micheal P. Todaro. 1989. Economic Development in the Third World. Fourth Edition. Longman Inc.

9. $\quad$ PGK bagi Semenanjung Malaysia dari Rancangan Malaysia Kelapan (RMK8), Unit Perancang Ekonomi Malaysia

10. Jumlah Jurang Kemiskinan $=\sum_{k=0}^{H}(\mathrm{Yp}-\mathrm{Yi})=\sum_{k=0}^{H}(\mathrm{Yp}-\mathrm{Yi})$ , di mana Yp ialah PGK dan Yi pendapatan isi rumah miskin yang ke i.

11. $\mathrm{FGT} \alpha=(1 / \mathrm{N}) \sum((\mathrm{Yp}-\mathrm{Yi}) / \mathrm{Yp}) 2$. Dalam kajian ini, $\alpha=2, \mathrm{~N}=4769$, $\mathrm{Yp}=6120$ dan Yi ialah pendapatan isi rumah miskin yang ke i. Perhatikan, apabila $\alpha=0$, indeks FGT menjadi nisbah head count, $\alpha=1$ menjadi jurang kemiskinan untuk mengukur intensiti kemiskinan, dan $\alpha=2$ indeks tersebut boleh mencerminkan teruknya kemiskinan. Dengan perkataan lain, apabila $\alpha$ meningkat indeks ini memberi lebih ruang kepada pendapatan paling bawah. (rujuk Ravallion et al, 1991). Indeks ini sangat popular digunakan kerana selain daripada daya tarikannya yang memiliki ciri-ciri indeks yang diingini, ia boleh dicerakinkan kepada kumpulan-kumpulan kecil. Ini bermakna, 
sekiranya terdapat kumpulan-kumpulan kecil isi rumah yang "saling menyingkir", yang digabungkan melalui wilayah, sektor, pekerjaan atau apa jua gabungan-gabungan lain, maka indeks keseluruhan kemiskinan FGT boleh disebut sebagai indeks kemiskinan jumlah penduduk berwajaran jumlah kemiskinan sesama kumpulan kecil. Maka jika Ps mewakili anggaran kemiskinan sesama kumpulan kecil s, kemsiskinan keseluruhan dapat dinyatakan sebagai,

$P s=\sum s i$ WsPs

Di mana Ws mewakili sumbangan kumpulan kecil $s$ kepada jumlah penduduk. (rujuk Foster, Greer \& Thorbecke, 1984)

12. Indeks Gini bagi pendapatan individu (mengambil kira taburan penerima pendapatan sahaja, tanpa mengira responden yang tidak memperolehi pendapatan) 0.401 . Didapati, 0.2542 dari keseluruhan indeks tersebut disumbangkan oleh pendapatan pekerjaan bergaji. Manakala, hanya 0.147 sahaja yang disumbangkan oleh pendapatan-pendapatan lain.

13. Lihat Anand (1970), Ikemoto (1980) dan Shireen (1998). Kajian lanjutan untuk mencerakinkan agihan pendapatan yang disebabkan oleh ketidaksetaraan "dalam kumpulan etnik" dan yang "antara kumpulan etnik" boleh dilakukan dengan menggunakkan kaedah indeks Theil.

\section{Rujukan}

Brandolini, A. (2001). Measuring well-being in the functioning space. Paper presented at the $26^{\text {th }}$ General Conference of the International Association for Research in Income and Wealth, Cracow, Poland.

Cheng Fang et. al. (2002). Emergence of urban poverty and inequality in China: Evidence from household survey. China Economics Review, 13, 430-443.

Fangwei $\mathrm{Wu}$ et. al. (2006). Unequal education, poverty and low growth - A theoretical framework for rural educatian of China. Economics of Education Review.

Foster, J., Greer, J., \& Thorbecke, E. (1984). A class of decomposable poverty measures. Econometrica, 52(3), 761-765.

Frederick, N., Bernard, W. (2006). Privatization, income distribution and poverty. World Development, 34, 1557-1579.

IJMS 18 (1), 173-196 (2011) 
Galor et. al. (1993). Income distribution and macroeconomics. Review of Economic Studies, 6, 35-52.

Haveman, R., \& Bershadker, A. (2001). The inability to be self-reliant as an indicator of poverty: Trends for the U.S. 1975-97. Review of Income and Wealth, 47(3), 335-360.

http://www.ncer.com.my

http://www.perak.gov.my

James, E. R. (1991). Economic development, urban underemployment and income inequality. National Bureau of Economic Research. Retrieve from http://www.nber.org/papers/w3758

Jon, A. (2007). Alleviating poverty in remote indigenous Australia: The role of the hybrid economy. Development Bulletin, 72, 47-51.

Lerman, R. I., Yitzhaki, S. (1985) Income inequality effects by income source: A new approach and applications to USA. Review of Economics and Statistics, 67, 151-156.

Miliakere, K. (2007). Fiji approach to addressing poverty. Development Bulletin, 72, 71-73.

Orlando, S. (2004). Development and income distribution: The case of Puerto Rico. World Development, 32, 1395-1406.

Patrick, K. (2007). The white paper on Australian Aid: Approaches to poverty. Development Bulletin, 72, 44-46.

Rati, Ram. (1984). Population increase, economic growth, educational inequality and income distribution. Journal of Development Economics, 14, 419-428.

Ravallion, M. Datt, G., \& Dominique van de Walle. (1991) Quantifying absolute poverty in the developing world, Review of Income and Wealth 37, 354-55.

Renuka Mahadevan. (June, 2006). Growth with equity: The Malaysian case. Asia-Pacific Development Journal, 31, 27-52.

Richard H., Adams Jr. John. (2003). Poverty, inequality and growth in selected middle east and North Africa Countries, 1980-2000. World Development, 31, 2027-2048.

Robert, E. L., Donald, W. V. (1996). Growth and income distribution in Malaysia. International Labour Review. 135, 554-575.

Sen, A. (1987). Commodities and capabilities. New Delhi: Oxford University Press.

Sen, A. (1999). Commodities and capabilities. New Delhi: Oxford University Press.

Stuart, R. L. (2003). Economic development: Theory and practice for a divided world. Pearson Education.

William, J. B. (2007). On income distribution and growth. Journal of Policy Modelling, 29, 545-548. 